\title{
A Test-Retest Paradigm of the Forced Swimming Test in Female Mice Is Not Valid for Predicting Antidepressant-Like Activity: Participation of Acetylcholine and Sigma-1 Receptors
}

\author{
Jing $\mathrm{Su}^{1}$, Noriko Hato-Yamada ${ }^{2}$, Hiroaki Araki ${ }^{1}$, and Hiroyuki Yoshimura ${ }^{3 * *}$ \\ ${ }^{1}$ Department of Pharmacology and Pharmacy, Ehime University Graduate School of Medicine, \\ Toon-city, Ehime 791-0295, Japan \\ ${ }^{2}$ Department of Fundamental Nursing Sciences, Ehime Prefectural University of Health Sciences, \\ Tobe-cho, Ehime 791-2101, Japan \\ ${ }^{3}$ Behavioral Pharmacology Laboratory, Research Institute for Alternative Medicine, Toon-city, Ehime 791-0202, Japan
}

Received August 19, 2013; Accepted September 8, 2013

\begin{abstract}
The forced swimming test (FST) in mice is widely used to predict the antidepressant activity of a drug, but information describing the immobility of female mice is limited. We investigated whether a prior swimming experience affects the immobility duration in a second FST in female mice and whether the test-retest paradigm is a valid screening tool for antidepressants. Female ICR mice were exposed to the FST using two experimental paradigms: a single FST and a double FST in which mice had experienced FST once $24 \mathrm{~h}$ prior to the second trail. The initial FST experience reliably prolonged immobility duration in the second FST. The antidepressants imipramine and paroxetine significantly reduced immobility duration in the single FST, but not in the double FST. Scopolamine and the sigma-1 $(\sigma 1)$ antagonist NE-100 administered before the second trial significantly prevented the prolongation of immobility. Neither a $5-\mathrm{HT}_{1 \mathrm{~A}}$ nor a $5-\mathrm{HT}_{2 \mathrm{~A}}$ receptor agonist affected immobility duration. We suggest that the test-retest paradigm in female mice is not adequate for predicting antidepressant-like activity of a drug; the prolongation of immobility in the double FST is modulated through acetylcholine and $\sigma 1$ receptors.
\end{abstract}

Keywords: forced swimming test, antidepressant, acetylcholine receptor, sigma-1 receptor, female mouse

\section{Introduction}

In 1993, the U.S. Federal Drug Administration (FDA) encouraged the inclusion of both females and males in clinical trials, but the guidelines for clinical trials in the U.S., Japan, and the EU have rarely emphasized the analysis of drug data for each gender (1). Even the general considerations for clinical trials issued by the International Conference on Harmonization (2) have not yet appreciated the earnest concern from women who want to know whether the drug they are prescribed has proven effectiveness and safety in females. Antidepressant drugs, which are prescribed over a long period

*Corresponding author. rifam@silk.ocn.ne.jp

Published online in J-STAGE on October 26, 2013

doi: $10.1254 /$ jphs.13145FP of time to prevent the recurrence of depression, are no exception. The prevalence of mood disorders is higher in females than in males, and the effectiveness of antidepressants differs between genders $(3-5)$. Nevertheless, drug development processes for new antidepressant candidates rarely take female animals into consideration.

In experimental psychopharmacology, little attention has been paid to the effect of drugs on female behavior. The forced swimming test (FST) in mice, which was originally conceived by Porsolt (6), is a well-known and useful model for preclinical evaluation of the antidepressant properties of a drug. A review by Petit-Demouliere et al. (7) concluded that the FST in mice offers sufficient reliability, predictive validity, and low costs; and virtually all clinically used antidepressants reliably shorten the duration of immobility in the FST. Numerous studies have used male mice for the FST, but future preclinical 
screening of new antidepressant candidates should include females. The focus on male animals in behavioral analyses of drug effects may be attributable to the complications that endocrine changes during the estrous cycle create for the analysis of data from female animals. However, David et al. (8) found no difference in the immobility duration between male and female mice, and Bekku et al. (9) demonstrated no significant difference in immobility duration among the four estrous stages in female ICR mice.

Several investigators have observed the prolongation of immobility in male mice $(10,11)$; when mice were forced to swim for $15 \mathrm{~min}$ on the first day, followed by a 5-6-min retest $24 \mathrm{~h}$ later, the immobility duration was significantly longer than that in the first FST. Although this double FST was originally devised to provide reproducibility in rats (12), some investigators have applied the rat FST protocol to mice to ensure the consistency of immobility duration measurements between groups $(13-15)$. It remains, however, to be determined whether the immobility duration of female mice in the second FST is a valid screening tool for antidepressants. The double FST paradigm may include learning or memory processes not involved in the single FST, and it does allow for the possibility that drug action on learning or memory may be involved in the antidepressant-like effects of a drug. In contrast to Seligman's "learned helplessness" experiments (16) which were based on a behavioral disorder under uncontrollable circumstances that had been previously reinforced using classical conditioning, Porsolt et al. (6) proposed that an immobile posture following an inescapable situation was closely related to a feeling of despair and they termed this "behavioral despair." When mice were unpredictably put into a cylinder containing water, they manifested vigorous activities such as struggling, climbing, and swimming to escape from the cylinder and then displayed an immobile posture of floating without movement. In the double FST, it appears that this implicit memory, accompanied by an emotional response, may sensitize the animals to the cylinder with water, as it swiftly adopts an immobile posture in the second FST, leading to prolonged immobility. In this context, it would appear that the single FST is related to feeling or mood and that the double FST is related to an unpleasant memory. There is, however, little information about whether a prior exposure to a swimming test prolongs the immobility duration in female mice.

In the present study, we used female ICR mice and compared two experimental paradigms: in one, mice naïve to swimming were subjected to a single FST, and in the other, mice were exposed to the initial FST followed by a second test $24 \mathrm{~h}$ later (a double FST). We initially compared the immobility duration between female and male mice or between the single and double FSTs. Then, we confirmed the pre-exposure time needed to prolong the immobility duration in the second test. To prove the validity of the test-retest paradigm in female mice, we determined the effects of imipramine and paroxetine on the single and double FSTs in female mice. Although antidepressants decreased the prolonged immobility in the second FST in male mice $(13,14$, $17-19)$, little information concerning drug effects in female mice is available. We further investigated whether the immobility duration in the double FST involved learning and memory processes, using scopolamine, $(+)$-pentazocine, and NE-100 because acetylcholine (ACh) and sigma-1 $(\sigma 1)$ receptors are crucial in mediating memory deficits and cognitive disorders $(20-24)$. To elucidate the participation of 5-hydroxytryptamine (HT) neuronal activity in the immobility in female mice, we examined the effects of the $5-\mathrm{HT}_{1 \mathrm{~A}}$ receptor agonist tandospirone and the 5- $\mathrm{HT}_{2 \mathrm{~A}}$ receptor agonist (-)-2,5dimethoxy-4-iodo-amphetamine hydrochloride (DOI) on immobility duration in the two FST paradigms. Because drugs can affect general motor activity and produce a false positive FST result, we determined spontaneous motor activity at the dose of each drug that significantly altered immobility duration.

\section{Materials and Methods}

\section{Animals}

Albino female ICR mice were purchased from CLEA (Osaka) and were adapted to laboratory conditions for at least 2 weeks prior to the start of the experiment ( 8 weeks of age). Animals were housed 8 mice per cage and had free access to food and water. The cage floors were covered with wood shavings, and mice were handled once per week while the cages were cleaned. Temperature within the vivarium was controlled automatically at $23^{\circ} \mathrm{C} \pm 2{ }^{\circ} \mathrm{C}$ with a 12 -h light-dark cycle. Experiments were conducted in accordance with the National Institutes of Health guidelines and the Guide for Animal Experimentation of Ehime University Graduate School of Medicine.

\section{Forced swimming test}

All testing was recorded on videotape. For the single FST, a mouse was placed for 6 min into a glass-polycarbonate cylinder ( 25 -cm-high $\times 10$-cm-wide) filled to a depth of $12 \mathrm{~cm}$ with water maintained at $24^{\circ} \mathrm{C}(25)$. Immediately following the water exposure, the animal was removed from the cylinder and dried using a waterabsorbent pad. For mice that were exposed twice to the FST, on the first day, the mouse was placed into the 
cylinder filled to a depth of $12 \mathrm{~cm}$ with water maintained at $24^{\circ} \mathrm{C}$ for $15 \mathrm{~min}$ (except in experiment 2 using three different immersion times: 5, 10, and $15 \mathrm{~min}$ ). Immediately following the exposure to water, the animal was removed from the cylinder, dried using a water-absorbent pad, and returned to its home cage. At $24 \mathrm{~h}$ after the first test, the mouse was placed for 6 min into the cylinder filled with water at $24^{\circ} \mathrm{C}$.

\section{Behavioral testing}

Behavior testing was conducted between 0900 and $1200 \mathrm{~h}$. The immobility duration was measured by an observer who was kept unaware of the experimental conditions. During the FST, the observer depressed a key on an event recorder console for as long as the immobile posture occurred. The duration and frequency of immobility were recorded automatically via an interface and were analyzed by a computer program. In this study we measured the total time spent immobile only during the last $4 \mathrm{~min}$ of the testing trial.

To measure general motor activity, test cages (42-cmlong $\times 26$-cm-wide $\times 15$-cm-high) were identical to the home cages, except they had a transparent polycarbonate cover with holes for ventilation instead of a wire-mesh wall. The test was started immediately after placing a mouse into the test cage and lasted for $5 \mathrm{~min}$. Each test was recorded on videotape. Locomotion and rearing were observed as general motor activities (26) and the duration and frequency of each behavioral element were measured by an observer who was kept unaware of the experimental conditions.

\section{Drug administration}

Each drug or vehicle was administered between 0800 and $1000 \mathrm{~h}$, and behavioral testing was carried out 30 or 60 min afterward. Scopolamine hydrobromide (Nacalai Tesque, Inc., Kyoto) and methylscopolamine bromide (Nacalai Tesque) were dissolved in isotonic saline and intraperitoneally injected at the indicated times. Imipramine hydrochloride (Wako Pure Chemical Industries, Ltd., Tokyo) and paroxetine maleate (Sigma, St. Louis, MO, USA) were dissolved in isotonic saline and injected intraperitoneally $30 \mathrm{~min}$ before behavioral testing (27, $28)$. The (+)-pentazocine (Sigma) was suspended in $0.5 \%$ carboxymethylcellulose sodium salt (CMC, Nacalai Tesque) and administered subcutaneously $30 \mathrm{~min}$ before behavioral testing (13). NE-100 hydrochloride (kindly supplied by Taisyo Pharmaceuticals Co., Ltd., Tokyo) was dissolved in distilled water and administered orally at 4 doses $30 \mathrm{~min}$ before behavioral testing (13). Tandospirone dihydrogen citrate (kindly supplied by Sumitomo Pharmaceuticals Co., Ltd., Osaka) was dissolved in isotonic saline and administered orally $60 \mathrm{~min}$ before behavioral testing (29). The (-)-2,5-dimethoxy-4-iodoamphetamine hydrochloride (DOI, Sigma) was dissolved in isotonic saline and administered subcutaneously 60 min before behavioral testing (9).

\section{Experimental design}

Seven separate series of experiments were conducted. The first experiment was designed to examine whether pre-exposure to water altered the immobility duration during the second FST when comparing female with male mice. We used an equal number $(n=16)$ of each gender and subdivided them into single FST and double FST groups using a $2 \times 2$ factorial design. The second experiment was conducted to elucidate the pre-exposure time needed to prolong the immobility time of female mice in the second test. In this test, 32 female mice were randomly assigned to 4 groups of 8 mice each for no pre-exposure or pre-exposure to the FST for 5, 10, or 15 min. Based on the results of experiment 2, pre-exposure time was fixed for $15 \mathrm{~min}$ in the following experiments.

In the third experiment, we compared the effectiveness of imipramine and paroxetine at 4 different doses between the single and double FST paradigms in female mice. Fifty-six female mice were randomly assigned to 7 groups of 8 mice each to test the drug effects in the single FST and double FST protocols. In the fourth experiment, female mice were treated with scopolamine or methylscopolamine to examine whether a memory of the FST prolonged the immobility time during the second FST. Because memory consists of 3 different components (memorization, memory retention, and retrieval), we used 3 different injection times: $30 \mathrm{~min}$ before the first FST, immediately after the termination of the first FST, and $30 \mathrm{~min}$ before the second FST, respectively. For each injection time, 56 female mice were randomly divided to 7 groups of 8 mice each and were injected with saline, scopolamine $(0.5,1$, and $2 \mathrm{mg} / \mathrm{kg})$, or methylscopolamine $(0.5,1$, and $2 \mathrm{mg} / \mathrm{kg})$.

The fifth experiment was designed to investigate a possible role of $\sigma 1$ receptors in mediating the prolonged immobility time following pre-exposure to the FST. We used the $\sigma 1$-receptor agonist (+)-pentazocine and the $\sigma 1$-receptor antagonist NE-100, each at four different doses. Sixty-four female mice were randomly assigned to 8 groups of 8 mice each and treated with $(+)$-pentazocine (vehicle, $1,2.5$, and $5 \mathrm{mg} / \mathrm{kg}$ ) or NE-100 (vehicle, 0.25 , 0.5 , and $1 \mathrm{mg} / \mathrm{kg}$ ). In the sixth experiment, we determined whether $5-\mathrm{HT}_{1 \mathrm{~A}}$ or $5-\mathrm{HT}_{2 \mathrm{~A}}$ receptors were involved in the prolonged immobility time induced by two FST experiences. We treated 56 female mice, randomly assigned to 7 groups of 8 mice each, with the $5-\mathrm{HT}_{1 \mathrm{~A}}-$ selective agonist tandospirone (vehicle, $1,2.5$, and $5 \mathrm{mg} / \mathrm{kg}$ ) or the $5-\mathrm{HT}_{2 \mathrm{~A}}$ agonist (-)-DOI (vehicle, 0.5 , and $1 \mathrm{mg} / \mathrm{kg}$ ). 
In the seventh experiment, we examined general motor activity in 80 female mice, randomly assigned to 10 groups of 8 mice each, after treatment with the dose of scopolamine, imipramine, paroxetine, or NE-100 that effectively reduced the immobility time in the FST.

\section{Statistical analyses}

All data are expressed as means \pm standard error (S.E.). Significant differences among several independent groups were evaluated statistically using analysis of variance (ANOVA) for a completely randomized design and were subsequently confirmed using Tukey's honestly significant difference (HSD) test.

\section{Results}

Comparison of immobility duration between male and female mice or between single and double FSTs

ANOVA for a factorial design determined that a significant effect exists between the single and double FTSs $\left(F_{(1,28)}=50,146, P<0.01\right)$. Multiple comparisons with Tukey's test showed that in both female and male mice, the immobility duration was significantly higher in the double FST than in the single FST $(P<0.01$; Table 1). There was no significant difference between female and male mice.

The pre-exposure time needed to prolong the immobility duration in the second test

As shown in Table 2, ANOVA determined that there was a significant difference among the 4 groups $\left(F_{(3,28)}=\right.$ $59.553, P<0.01)$. Compared with the immobility duration in a no-exposure group, pre-exposure to water for 10 or 15 min significantly prolonged the immobility duration in the subsequent FST $(P<0.01)$. Pre-exposure for $5 \mathrm{~min}$, however, did not alter the immobility duration compared with that of a single FST.
Effects of antidepressants on the immobility duration

Table 3 describes the effects of the antidepressants imipramine and paroxetine on the immobility time. In the single FST, treatment with $20 \mathrm{mg} / \mathrm{kg}$ imipramine or 5 and $10 \mathrm{mg} / \mathrm{kg}$ paroxetine significantly decreased the immobility duration of the mice $\left(F_{(6,49)}=5.614, P<0.01\right)$. In mice exposed twice to the FST, neither imipramine nor paroxetine significantly affected the immobility duration in any of the treatment groups $\left(F_{(6,49)}=0.925\right.$, N.S.).

Table 1. Comparison of the immobility duration between male and female mice or between the single and double FSTs

\begin{tabular}{lll}
\hline & \multicolumn{2}{c}{ Immobility duration $(\mathrm{s})$} \\
\cline { 2 - 3 } & \multicolumn{1}{c}{ Male } & Female \\
\hline Single FST & $185.9 \pm 4.1$ & $184.3 \pm 3.9$ \\
Double FST & $219.5 \pm 4.5^{* *}$ & $213.6 \pm 4.1^{* *}$ \\
\hline
\end{tabular}

For the single FST, mice were placed for 6 min into a cylinder filled with water, and for the double FST, mice were pre-exposed to the FST for $15 \mathrm{~min}$, and twenty-four hours after the first test, the second FST were performed for $6 \mathrm{~min}$. Each value indicates the mean \pm S.E.M. for 8 animals. ${ }^{* *} P<0.01$, significantly different from the single FST group.

Table 2. Effect of pre-exposure time of FST on the immobility duration in the second test

\begin{tabular}{llc}
\hline Groups & $\mathrm{n}$ & Immobility duration (s) \\
\hline Non-exposure & 8 & $182.6 \pm 2.3$ \\
Pre-exposure for 5 min & 8 & $182.9 \pm 3.5$ \\
Pre-exposure for 10 min & 8 & $210.6 \pm 2.2^{* *}$ \\
Pre-exposure for 15 min & 8 & $224.0 \pm 2.5^{* *}$ \\
\hline
\end{tabular}

Each value indicates the mean \pm S.E.M. for 8 animals. $* * P<0.01$ vs. the non-exposure group.

Table 3. Effects of imipramine and paroxetine on the immobility duration in the single and the double FSTs

\begin{tabular}{lcccccc}
\hline \multirow{2}{*}{\begin{tabular}{l}
\multirow{2}{*}{ Groups } \\
Route
\end{tabular}} & \multirow{2}{*}{ Dose $(\mathrm{mg} / \mathrm{kg})$} & \multicolumn{4}{c}{ Immobility duration (s) } \\
\cline { 5 - 7 } & & & $\mathrm{n}$ & Single FST & $\mathrm{n}$ & Double FST \\
\hline Vehicle (Saline) & i.p. & 0 & 8 & $185.9 \pm 2.0$ & 8 & $222.1 \pm 4.1$ \\
\hline Imipramine & i.p. & 5 & 8 & $175.9 \pm 4.1$ & 8 & $224.3 \pm 3.9$ \\
& i.p. & 10 & 8 & $171.1 \pm 5.4$ & 8 & $220.2 \pm 3.7$ \\
& i.p. & 20 & 8 & $140.5 \pm 12.8^{* *}$ & 8 & $216.5 \pm 4.1$ \\
\hline Paroxetine & i.p. & 2.5 & 8 & $172.7 \pm 4.0$ & 8 & $214.1 \pm 5.0$ \\
& i.p. & 5 & 8 & $165.6 \pm 3.9^{*}$ & 8 & $220.3 \pm 3.8$ \\
& i.p. & 10 & 8 & $157.0 \pm 4.6^{* *}$ & 8 & $209.8 \pm 9.6$ \\
\hline
\end{tabular}

In the single FST, female mice were placed for 6 min into a cylinder filled with water. In the double FST, female mice were pre-exposed to the FST for $15 \mathrm{~min}$, and $24 \mathrm{~h}$ after the first test, the second FST for 6 min was performed. Imipramine and paroxetine were administered intraperitoneally $30 \mathrm{~min}$ before the behavioral testing. Each value indicates the mean \pm S.E.M. for 8 animals. ${ }^{*} P<0.05,{ }^{* *} P<0.01$ vs. the vehicle-treated group. 


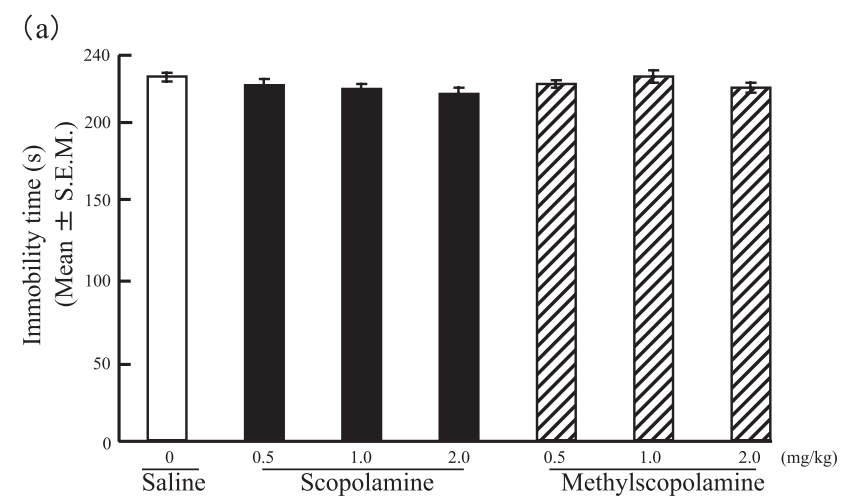

(b)
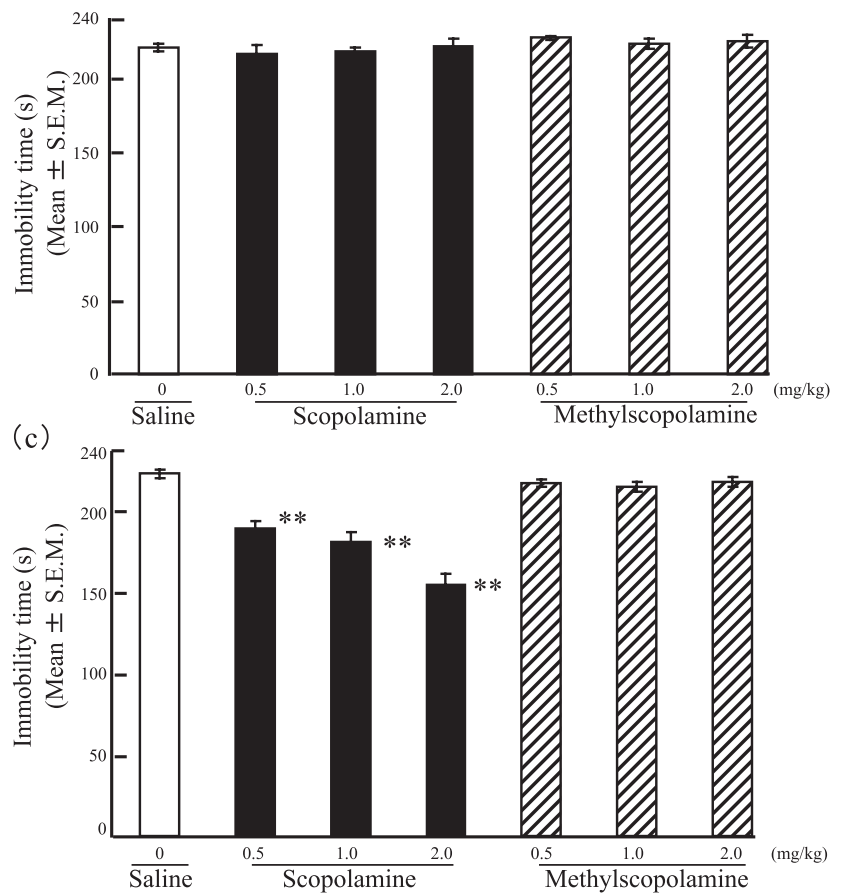

Fig. 1. Effect of scopolamine and methylscopolamine on immobility duration in the double FST. In this experiment, mice were pre-exposed to the FST for $15 \mathrm{~min}$, and $24 \mathrm{~h}$ after the first test, the second FST for 6 min was performed. The drugs were administered at three different timings: A) 30 min before the first FST, B) immediately after the first FST, and C) $30 \mathrm{~min}$ before the second FST. White columns show the vehicle-treated control, and vertical lines indicate means \pm S.E.M. for 8 animals. $* * P<0.01$, significantly different from the vehicle-treated group.

Effect of scopolamine on immobility duration in the FST

Scopolamine is an Ach-receptor antagonist known to produce an amnesia-like state in experimental animals $(30,31)$. In the present study, we compared its effect with that of methylscopolamine, which does not cross the blood-brain barrier, to distinguish between central and peripheral actions. Figure 1 shows the effects of different doses of scopolamine and methylscopolamine on immobility duration in the double FST. When scopolamine or methylscopolamine was administered $30 \mathrm{~min}$ before

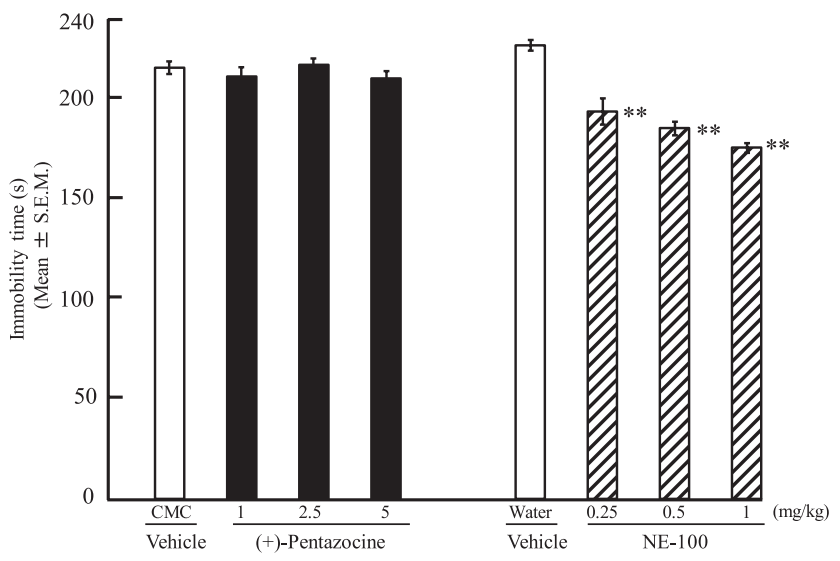

Fig. 2. Effect of (+)-pentazocine and NE-100 on immobility duration in the double FST. Mice were pre-exposed to the FST for $15 \mathrm{~min}$, and $24 \mathrm{~h}$ after the first test, the second FST for 6 min was performed. The (+)-pentazocine was administered subcutaneously and NE-100 was administered orally $30 \mathrm{~min}$ before the second FST. White columns show the vehicle-treated control, and vertical lines indicate means \pm S.E.M. for 8 animals. $* * P<0.01$, significantly different from the corresponding vehicle-treated group.

pre-exposure to the FST, neither drug showed a significant effect on the immobility duration in the second FST $\left(F_{(6,49)}=1.444\right.$, N.S.) (Fig. 1a). Similarly, neither scopolamine nor methylscopolamine administered immediately after the first FST altered the immobility duration in the second FST $\left(F_{(6,49)}=0.913\right.$, N.S.) (Fig. 1b). The immobility duration differed significantly among the groups when the drugs were administrated $30 \mathrm{~min}$ before the second FST $\left(F_{(6,49)}=35.907, P<0.01\right)$. Compared with vehicle treatment, the acute administration of scopolamine significantly shortened the immobility duration in a dose-dependent manner $(P<0.01)$. In contrast, methylscopolamine at all doses failed to alter the immobility duration (Fig. 1c).

\section{Role of $\sigma 1$ receptors in immobility duration}

To elucidate the participation of $\sigma 1$ receptors in the alteration of immobility duration induced by two exposures to the FST, we used a $\sigma 1$-receptor agonist, (+)pentazocine, and a $\sigma 1$-receptor antagonist, NE-100 (Fig. 2). Treatment with (+)-pentazocine did not significantly affect the immobility duration $\left(F_{(3,28)}=0.819\right.$, N.S.). However, compared with vehicle alone, all doses of NE-100 significantly shortened the immobility duration in the second FST $\left(F_{(3,28)}=30.994, P<0.01\right)$.

\section{Effects of 5-HT $T_{1 A}$ and 5-HT $T_{2 A}$ receptor agonists on im-} mobility duration

Agonists of 5- $\mathrm{HT}_{1 \mathrm{~A}}$ and $5-\mathrm{HT}_{2 \mathrm{~A}}$ receptors have been reported to affect the immobility duration in a single FST $(9,23,32)$. We treated animals with the $5-\mathrm{HT}_{1 \mathrm{~A}}$ receptor 
Table 4. Effects of tandospirone and (-)-DOI on the duration of immobility in the single and the double FSTs

\begin{tabular}{|c|c|c|c|c|c|c|}
\hline \multirow{2}{*}{ Groups } & \multirow{2}{*}{ Route } & \multirow{2}{*}{ Dose (mg/kg) } & \multicolumn{4}{|c|}{ Immobility duration (s) } \\
\hline & & & $\mathrm{n}$ & Single FST & $\mathrm{n}$ & Double FST \\
\hline Vehicle (water) & p.o. & 0 & 8 & $187.0 \pm 4.7$ & 8 & $219.8 \pm 4.1$ \\
\hline \multirow[t]{3}{*}{ Tandospirone } & p.o. & 1 & 8 & $193.5 \pm 4.6$ & 8 & $228.1 \pm 2.0$ \\
\hline & p.o. & 2.5 & 8 & $190.2 \pm 3.7$ & 8 & $227.0 \pm 2.2$ \\
\hline & p.o. & 5 & 8 & $188.1 \pm 4.5$ & 8 & $220.4 \pm 2.0$ \\
\hline Vehicle (saline) & s.c. & 0 & 8 & $183.1 \pm 5.0$ & 8 & $223.3 \pm 3.0$ \\
\hline \multirow[t]{2}{*}{$(-)-\mathrm{DOI}$} & s.c. & 0.5 & 8 & $191.2 \pm 7.3$ & 8 & $223.6 \pm 2.9$ \\
\hline & s.c. & 1 & 8 & $183.9 \pm 3.3$ & 8 & $223.9 \pm 3.2$ \\
\hline
\end{tabular}

In the single FST, female mice were placed for 6 min into a cylinder filled with water. In the double FST, female mice were pre-exposed to the FST for $15 \mathrm{~min}$, and $24 \mathrm{~h}$ after the first test, the second FST for 6 min was performed. Tandospirone was administered orally 60 min before behavioral testing, while (-)-DOI was administered subcutaneously $60 \mathrm{~min}$ before behavioral testing. Each value indicates the mean \pm S.E.M. ANOVA revealed that there was no significant difference in the duration of immobility among the 7 experimental groups.

Table 5. Effect of drugs, at the effective doses on the immobility time, on general motor activities

\begin{tabular}{lccccc}
\hline \multirow{2}{*}{ Drugs } & \multicolumn{2}{c}{ Locomotion } & & \multicolumn{2}{c}{ Rearing } \\
\cline { 2 - 3 } \cline { 5 - 6 } & Frequency & Duration & & Frequency & Duration \\
\hline Vehicle & $96.6 \pm 2.9$ & $120.3 \pm 4.8$ & & $56.3 \pm 4.1$ & $71.2 \pm 6.6$ \\
Scopolamine $(1 \mathrm{mg} / \mathrm{kg})$ & $90.0 \pm 2.9$ & $135.0 \pm 5.0$ & & $59.3 \pm 4.4$ & $61.7 \pm 5.5$ \\
Scopolamine $(2 \mathrm{mg} / \mathrm{kg})$ & $91.5 \pm 3.0$ & $136.0 \pm 4.9$ & & $41.1 \pm 6.0$ & $44.0 \pm 7.7$ \\
Imipramine $(10 \mathrm{mg} / \mathrm{kg})$ & $88.2 \pm 3.4$ & $118.5 \pm 5.4$ & & $51.8 \pm 5.6$ & $67.1 \pm 9.5$ \\
Imipramine $(20 \mathrm{mg} / \mathrm{kg})$ & $86.8 \pm 4.1$ & $122.5 \pm 7.2$ & & $48.8 \pm 3.9$ & $61.3 \pm 8.2$ \\
Paroxetine $(5 \mathrm{mg} / \mathrm{kg})$ & $85.1 \pm 4.0$ & $122.9 \pm 7.6$ & & $48.0 \pm 5.5$ & $60.7 \pm 7.2$ \\
Paroxetine $(10 \mathrm{mg} / \mathrm{kg})$ & $91.9 \pm 3.3$ & $136.2 \pm 7.2$ & & $56.4 \pm 3.9$ & $63.9 \pm 2.9$ \\
NE-100 $(0.25 \mathrm{mg} / \mathrm{kg})$ & $88.3 \pm 3.9$ & $112.2 \pm 4.4$ & & $58.6 \pm 4.8$ & $72.7 \pm 4.1$ \\
NE-100 $(0.5 \mathrm{mg} / \mathrm{kg})$ & $92.0 \pm 4.6$ & $115.5 \pm 5.1$ & & $55.4 \pm 4.0$ & $71.9 \pm 5.1$ \\
NE-100 $(1 \mathrm{mg} / \mathrm{kg})$ & $93.0 \pm 2.8$ & $124.6 \pm 6.2$ & & $56.2 \pm 6.1$ & $67.9 \pm 8.5$ \\
\hline
\end{tabular}

Each value indicates the mean \pm S.E.M. for 8 animals. ANOVA revealed that there was no significant difference in each item among 10 groups.

agonist tandospirone or the 5- $\mathrm{HT}_{2 \mathrm{~A}}$ receptor agonist (-)DOI and measured their effects on the immobility duration (Table 4). There was no significant difference in the immobility duration among the treatment groups exposed to a single FST $\left(F_{(6,49)}=0.534\right.$, N.S. $)$ or among those exposed twice to the test $\left(F_{(6,49)}=1.008\right.$, N.S. $)$.

\section{Effects of drug treatments on general motor activity}

As motor activity can be particularly enhanced by drug treatment, creating a false positive FST result, we determined the spontaneous motor activity of mice treated with the effective doses of the drugs that significantly altered the immobility duration (Table 5). According to ANOVA, spontaneous motor activity did not differ significantly between drug-treated and vehicle-treated groups based on the frequency of locomotion $\left(F_{(9,70)}=\right.$ 0.786 , N.S. $)$, the duration of locomotion $\left(F_{(9,70)}=1.886\right.$,
N.S. $)$, the frequency of rearing behavior $\left(F_{(9,70)}=1.191\right.$, N.S.), or the duration of rearing behavior $\left(F_{(9,70)}=1.595\right.$, N.S.).

\section{Discussion}

Our results clearly demonstrate that a prior swimming experience significantly prolongs the immobility duration in female ICR mice during a second FST. Consistent with previous reports $(10,11)$, this phenomenon was also observed in male mice. Interestingly, prolonged immobility duration was dependent upon the pre-exposure time period: a 5-min pre-exposure was not sufficient to alter the immobility duration in a second FST, whereas 10 - and 15-min pre-exposure periods significantly prolonged the immobility duration in a second FST. Andreatini and Bacellar (33) reported a poor intra-class 
correlation coefficient (0.05) in male Swiss mice using a test-retest experimental design with a 1-week interval, arguing that the FST lacked the stability and reliability for screening antidepressant drugs. However, a close examination of their data reveals significantly prolonged immobility duration in the second FST, indicative of mice learning to cope with an inescapable situation, as described by West (34), rather than a lack of stability and reliability. Although the ethological meaning of floating with an immobile posture remains unclear, mice quickly learn that escape from the situation is impossible and apparently cope by saving their energy (34). During a second FST, mice appear to recall the previous experience and immediately adopt an immobile posture.

In the present study, the antidepressants imipramine and paroxetine significantly reduced the immobility duration only in a single FST; the drugs failed to decrease the immobility duration in the second FST trial. This is inconsistent with studies in male mice, where an acute injection of imipramine, desipramine, or fluoxetine, using the same treatment paradigm described here, significantly reduced the immobility duration in the second trial $(13,14,17-19)$. Thus, there appears to be a different effectiveness of antidepressants between male and female mice. Interestingly, a clinical report also suggested that males responded better to imipramine than women (35). Because the majority of experiments in male mice have used the single FST paradigm and because antidepressants, including imipramine and paroxetine, decreased immobility duration in these experiments $(8,28,36)$, a single FST in mice may be preferable for predicting the antidepressant-like activity of a candidate drug. In any event, the double FST in female mice is not adequate for predicting the antidepressant-like activity of unknown substances. It remains unsolved, however, whether chronic treatments with antidepressant drugs are effective in the double FST in female mice.

To investigate the role of learning and memory in the FST response, we injected the amnesic drug scopolamine at different times during the experimental protocol. Scopolamine dose-dependently shortened the prolonged immobility duration observed during the second FST only when injected $30 \mathrm{~min}$ before the trial. This agrees with previous reports describing decreased immobility duration in male rats administered scopolamine at 30 or $60 \mathrm{~min}$ before the second trial $(37,38)$. By contrast, scopolamine failed to alter the immobility duration in the second FST when scopolamine was injected at either $30 \mathrm{~min}$ before or immediately after the first FST. Thus, our findings suggest that in double FST paradigm scopolamine may not impair the acquisition and retention of memory process: namely, the action of scopol- amine may be due to an effect on memory retrieval. In the literaturs, however, there is a diversity of reports concerning the mechanism of scopolamine's amnesic effect on learning/memory, which appears to depend on the experimental manipulation employed (e.g., single vs. multiple task, conditioned vs. unconditioned learning, or procedural vs. episodic memory). Our finding, showing that scopolamine did not affect the retention of memory process, is consistent with previous report that scopolamine at 2 or $2.5 \mathrm{mg} / \mathrm{kg}$ when injected immediately after the first FST of mice did not affect the immobility duration in the second FST $(10,39)$. In male rats, however, De Pablo et al. (40) indicated that when administered immediately after the first FST, scopolamine significantly increased the mobility counts (electrical units, not duration time) in the second FST. They showed only the percentage of change in relation to subject's number of impulses during the first $5 \mathrm{~min}$ of the first trial, but did not show any base levels in each experiment. Thus, it appears that there exist some methodological implications for the interpretation of the FST. Methylscopolamine, which does not easily cross the blood-brain barrier, did not alter the immobility duration at the least effective dose levels of scopolamine, irrespective of injection timing. This suggests that the decrease in the immobility duration following the injection of scopolamine is attributable to its anticholinergic action in the brain.

Increasing evidence has demonstrated that $\sigma 1$ receptors are involved in learning and memory processes, particularly improvements in memory deficits and cognitive disorders $(20-22)$. Interestingly, $\sigma 1$ receptors modulate cholinergic and glutaminergic pathways through calcium channels and display powerful antiamnesic and neuroprotective effects in animal models of cognitive dysfunction (22). The $\sigma 1$-receptor agonists $(+)$-SKF 10047 and $( \pm)$-pentazocine increased ACh release in the hippocampus and frontal cortex (22). In contrast, the $\sigma 1$ antagonist NE-100 was ineffective by itself, but antagonized the effects elicited by the $\sigma 1$ agonist PRE-084 on learning and memory impairment induced by carbon monoxide (41). Additionally, NE-100 did not affect learning impairment induced by scopolamine (42) or dizocilpine (43) in male mice, whereas it reversed the effects of $\sigma 1$ agonists.

While an antagonistic effect of NE-100 has been reported repeatedly (e.g., 21, 41), little attention has been paid to its amnesic-like effect. Our findings demonstrate that NE-100 dose-dependently prevented the prolongation of immobility in the second FST, and (+)-pentazocine was ineffective. Thus, NE-100 may produce a scopolamine-like amnesic effect and/or may impair memory retrieval of the first FST. Alternatively, the 
prolongation of immobility during the repeated FST may be mediated through the activation of $\sigma 1$ receptors, although this is not supported by the literature in male mice. For example, in male Swiss OF1 mice, $\sigma 1$-receptor agonists such as igmesine and (+)-SKF-10047, but not the antagonist BD1047, decreased the immobility duration in the second FST (14). The same result was reported in male ddY mice treated with either $(+)$-pentazocine or NE-100 (13). As mentioned by Urani et al. (14), the immobility duration was $180 \pm 4 \mathrm{~s}$ during the last $4 \mathrm{~min}$ of the first trial and increased significantly to $227 \pm 5 \mathrm{~s}$ in the second trial performed $24 \mathrm{~h}$ later. In the present study, the measured immobility durations in ICR male mice were $185.9 \pm 4.1 \mathrm{~s}$ in the first trial and $219.5 \pm 4.5 \mathrm{~s}$ in the second trial, indicating that the immobility duration was increased in the second FST independent of the strain. However, possible gender differences in $\sigma 1$ receptor responses remain to be determined. Interestingly, bilateral ovariectomy in female mice significantly prolonged the immobility duration $(9,25,44)$, and neurosteroids, which are closely related to sex hormones, modulate $\sigma 1$ receptors $(45,46)$.

Current evidence indicates that $5-\mathrm{HT}_{1 \mathrm{~A}}$ receptors play an important role in mediating the induction of memory impairment (47) and depression (48). Serotonin interacts with the cholinergic, glutaminergic, dopaminergic, and GABAnergic systems, and thus the observed behavioral effects of $5-\mathrm{HT}_{1 \mathrm{~A}}$ receptor agonists vary across studies $(49,50)$. Nevertheless, the stimulation of $5-\mathrm{HT}_{1 \mathrm{~A}}$ or $5-\mathrm{HT}_{2 \mathrm{~A}}$ receptors is involved in the psychotropic action of antidepressant drugs $(51,52)$. In the present study, neither the 5- $\mathrm{HT}_{1 \mathrm{~A}}$ receptor agonist tandospirone nor the $5-\mathrm{HT}_{2 \mathrm{~A}}$ receptor agonist (-)-DOI affected the immobility duration in the FST experiments. Our findings with tandospirone are consistent with previous reports showing that 8 -OH-DPAT, also a $5-\mathrm{HT}_{1 \mathrm{~A}}$ receptor agonist, did not affect immobility duration of male mice $(53,54)$. Both acute and chronic treatment with (-)-DOI dose-dependently prevented the prolongation of immobility induced by ovariectomy (9); however, (-)-DOI failed to reduce immobility time during the second FST in the present study, which is consistent with previous results for a single FST (55). These findings suggest that a different mechanism may underlie the prolongation of immobility with repeated FSTs.

In the present study, none of the drugs affected the duration or frequency of locomotion and rearing, indicating that they did not augment general motor activity in mice. Therefore, we can eliminate the possibility that the antidepressant-like effect of the drugs might have been concealed by a drug-induced augmentation of motor behavior.

In conclusion, female mice displayed prolonged immobility duration in a second FST, and antidepressants failed to show any significant effect on the immobility duration of female mice exposed twice to the FST. The prolongation of immobility duration was prevented by scopolamine or NE-100 administered prior to the second trial. This suggests that $\mathrm{ACh}$ and $\sigma 1$ receptors may play a role in the response to the test-retest paradigm. We propose that the test-retest paradigm is inadequate for detecting antidepressant-like activity of a drug, possibly because the repetition of the FST may involve a memory process that cannot be eliminated.

\section{References}

1 Lippman A. The inclusion of women in clinical trials: are we asking the right questions? Toronto: Women and Health Protection; 2006.

2 ICH Steering Committee. General considerations for clinical trials. ICH harmonized tripartite guideline. 1997.

3 Goodnick PJ, Chaudry T, Artadi J, Arcey S. Women's issues in mood disorders. Expert Opin Pharmacother. 2000;1:903-916.

4 Sagud M, Hotujac L, Mihaljevic-Peles A, Jakovljevic M. Gender differences in depression. Coll Antropol. 2002;26:149-157.

5 Sloan DM, Kornstein SG. Gender differences in depression and response to antidepressant treatment. Psychiatr Clin North Am. 2003;26:581-594.

6 Porsolt RD, Bertin A, Jalfre M. Behavioral despair in mice: a primary screening test for antidepressants. Arch Int Pharmacodyn Ther. 1977;229:327-336.

7 Petit-Demouliere B, Chenu F, Bourin M. Forced swimming test in mice: a review of antidepressant activity. Psychopharmacology (Berl). 2005;177:245-255.

8 David DJ, Renard CE, Jolliet P, Hascoet M, Bourin M. Antidepressant-like effects in various mice strains in the forced swimming test. Psychopharmacology (Berl). 2003;166:373-382.

9 Bekku N, Yoshimura H, Araki H. Factors producing a menopausal depressive-like state in mice following ovariectomy. Psychopharmacology (Berl). 2006;187:170-180.

10 Tadano T, Abe Y, Morikawa Y, Hozumi M, Nakagawasaki O, Tan-No K, et al. [Relationship between learning behavior and genetic factor on immobility shown during forced swimming test]. Nihon Shinkei Seishin Yakurigaku Zasshi. 1997;17:129135. (text in Japanese)

11 Alcaro A, Cabib S, Ventura R, Puglisi-Allegra S. Genotype- and experience-dependent susceptibility to depressive-like responses in the forced-swimming test. Psychopharmacology (Berl). 2002;164:138-143.

12 Porsolt RD, Anton G, Blavet N, Jalfre M. Behavioural despair in rats: a new model sensitive to antidepressant treatments. Eur J Pharmacol. 1978;47:379-391.

13 Matsuno K, Kobayashi T, Tanaka MK, Mita S. Sigma 1 receptor subtype is involved in the relief of behavioral despair in the mouse forced swimming test. Eur J Pharmacol. 1996;312: 267-271.

14 Urani A, Roman FJ, Phan VL, Su TP, Maurice T. The antidepressant-like effect induced by sigma(1)-receptor agonists and neuroactive steroids in mice submitted to the forced swimming test. J Pharmacol Exp Ther. 2001;298:1269-1279.

15 Hirani K, Khisti RT, Chopde CT. Behavioral action of ethanol in 
Porsolt's forced swim test: modulation by 3 alpha-hydroxy- 5 alpha-pregnan-20-one. Neuropharmacology. 2002;43:1339-1350.

16 Seligman ME. Learned helplessness. Annu Rev Med. 1972;23:407-412.

17 Emamghoreishi M, Talebianpour MS. Antidepressant effect of Melissa officinalis in the forced swimming test. Daru. 2009; 17:42-47.

18 Villard V, Meunier J, Chevallier N, Maurice T. Pharmacological interaction with the sigma1 $(\sigma 1)$-receptor in the acute behavioral effects of antidepressants. J Pharmacol Sci. 2011;115:279-292.

19 Wang R, Xu Y, Wu HL, Li YB, Li YH, Guo JB, et al. The antidepressant effects of curcumin in the forced swimming test involve 5-HT 1 and 5- $\mathrm{HT}_{2}$ receptors. Eur J Pharmacol. 2008;578:43-50.

20 Maurice T, Lockhart BP. Neuroprotective and anti-amnesic potentials of $\sigma 1$ receptor ligands. Prog Neuropsychopharmacol Biol Psychiatry. 1997;21:69-102.

21 Bermack JE, Debonnel G. Modulation of serotonergic neurotransmission by short- and long-term treatments with sigma ligands. Br J Pharmacol. 2001;134:691-699.

22 van Waarde A, Ramakrishnan NK, Rybczynska AA, Elsinga PH, Ishiwata K, Nijholt IM, et al. The cholinergic system, sigma-1 receptors and cognition. Behav Brain Res. 2011;221:543-554.

23 Busquet P, Capurro V, Cavalli A, Piomelli D, Reggiani A, Bertorelli R. Synergistic effects of galantamine and memantine in attenuating scopolamine-induced amnesia in mice. J Pharmacol Sci. 2012;120:305-309.

24 Yamamoto Y, Shioda N, Han F, Moriguchi S, Fukunaga K. The novel cognitive enhancer ST101 enhances acetylcholine release in mouse dorsal hippocampus through T-type voltage-gated calcium channel stimulation. J Pharmacol Sci. 2013;121:212-226.

25 Yamada N, Araki H, Yoshimura H. Identification of antidepressant-like ingredients in ginseng root (Panax ginseng C.A. Meyer) using a menopausal depressive-like state in female mice: participation of 5-HT2A receptors. Psychopharmacology (Berl). 2011;216:589-599.

26 Carr MN, Bekku N, Yoshimura H. Identification of anxiolytic ingredients in ginseng root using the elevated plus-maze test in mice. Eur J Pharmacol. 2006;531:160-165.

27 Sugimoto Y, Furutani S, Nishimura K, Itoh A, Tanahashi T, Nakajima H, et al. Antidepressant-like effects of neferine in the forced swimming test involve the serotonin1A (5-HT1A) receptor in mice. Eur J Pharmacol. 2010;634:62-67.

28 Sugimoto Y, Yamamoto M, Tagawa N, Kobayashi Y, MitsuiSaitoh K, Hotta Y, et al. Differences between mice strains in response to paroxetine in the forced swimming test: involvement of serotonergic or noradrenergic systems. Eur J Pharmacol. 2011;672:121-125.

29 Yoshimura H, Ogawa N. Ethopharmacology of maternal aggression in mice: effects of diazepam and SM-3997. Eur J Pharmacol. 1991;23:147-153.

30 Beatty WW, Butters N, Janowsky DS. Patterns of memory failure after scopolamine treatment: implications for cholinergic hypotheses of dementia. Behav Neural Biol. 1986;45:196-211.

31 Flood JF, Cherkin A. Scopolamine effects on memory retention in mice: a model of dementia? Behav Neural Biol. 1986;45:169-184.

32 Biala G. Antidepressant-like properties of some serotonin receptor ligands and calcium channel antagonists measured with the forced swimming test in mice. Pol J Pharmacol. 1998; $50: 117-124$.
33 Andreatini R, Bacellar LF. Animal models: trait or state measure? The test-retest reliability of the elevated plus-maze and behavioral despair. Prog Neuropsychopharmacol Biol Psychiatry. 2000;24:549-560.

34 West AP. Neurobehavioral studies of forced swimming: the role of learning and memory in the forced swim test. Prog Neuropsychopharmacol Biol Psychiatry. 1990;14:863-877.

35 Vermeiden M, van den Broek WW, Mulder PG, Birkenhäger TK. Influence of gender and menopausal status on antidepressant treatment response in depressed inpatients. J Psychopharmacol. 2010;24:497-502.

36 Borsini F, Meli A. Is the forced swimming test a suitable model for revealing antidepressant activity? Psychopharmacology (Berl). 1988;94:147-160.

37 Mancinelli A, Borsini F, d'Aranno V, Lecci A, Meli A. Cholinergic drug effects on antidepressant-induced behaviour in the forced swimming test. Eur J Pharmacol. 1988;158:199-205.

38 Jutkiewicz EM, Rice KC, Woods JH, Winsauer PJ. Effects of the delta-opioid receptor agonist SNC80 on learning relative to its antidepressant-like effects in rats. Behav Pharmacol. 2003; 14:509-516.

39 Parra A, Vinader-Caerols C, Monleón S, Simón VM. Learned immobility is also involved in the forced swimming test in mice. Psicothema. 1999;11:239-246.

40 De Pablo JM, Ortiz-Caro J, Sanchez-Santed F, Guillamon A. Effects of diazepam, pentobarbital, scopolamine and the timing of saline injection on learned immobility in rats. Physiol Behav. 1991;50:895-899.

41 Maurice T, Phan VL, Noda Y, Yamada K, Privat A, Nabeshima T. The attenuation of learning impairments induced after exposure to $\mathrm{CO}$ or trimethyltin in mice by sigma (sigma) receptor ligands involves both sigma1 and sigma2 sites. $\mathrm{Br} \mathrm{J}$ Pharmacol. 1999; 127:335-342.

42 Urani A, Privat A, Maurice T. The modulation by neurosteroids of the scopolamine-induced learning impairment in mice involves an interaction with $\sigma 1$ receptors. Brain Res. 1998; 799:64-77.

43 Maurice T, Hiramatsu M, Itoh J, Kameyama T, Hasegawa T, Nabeshima T. Behavioral evidence for a modulating role of sigma ligands in memory processes. I. Attenuation of dizocilpine (MK-801)-induced amnesia. Brain Res. 1994;647:44-56.

44 Bekku N, Yoshimura H. Animal model of menopausal depressive-like state in female mice: prolongation of immobility time in the forced swimming test following ovariectomy. Psychopharmacology (Berl). 2005;183:300-307.

45 Maurice T. Neurosteroids and sigma1 receptors, biochemical and behavioral relevance. Pharmacopsychiatry. 2004;37 Suppl 3:S171-S182.

46 Maurice T, Gregoire C, Espallergues J. Neuro(active)steroids actions at the neuromodulatory $\sigma 1$ receptor: biochemical and physiological evidences, consequences in neuroprotection. Pharmacol Biochem Behav. 2006;84:581-597.

47 Buhot MC, Martin S, Segu L. Role of serotonin in memory impairment. Ann Med. 2000;32:210-221.

48 Savitz J, Lucki I, Drevets WC. 5- $\mathrm{HT}_{1 \mathrm{~A}}$ receptor function in major depressive disorder. Prog Neurobiol. 2009;88:17-31.

49 Lucki I, Singh A, Kreiss DS. Antidepressant-like behavioral effects of serotonin receptor agonists. Neurosci Biobehav Rev. 1994;18:85-95.

50 Borsini F. Role of the serotonergic system in the forced swim- 
ming test. Neurosci Biobehav Rev. 1995;19:377-395.

51 Hascoet M, Bourin M, Colombel MC, Fiocco AJ, Baker GB. Anxiolytic-like effects of antidepressants after acute administration in a four-plate test in mice. Pharmacol Biochem Behav. 2000;65:339-344.

52 Bourin M, Masse F, Dailly E, Hascoet M. Anxiolytic-like effect of milnacipran in the four-plate test in mice: mechanism of action. Pharmacol Biochem Behav. 2005;81:645-656.

53 Bourin M, Redrobe JP, Baker GB. Pindolol does not act only on
$5-\mathrm{HT}_{1 \mathrm{~A}}$ receptors in augmenting antidepressant activity in the mouse forced swimming test. Psychopharmacology (Berl). 1998;136:226-234.

54 Einat H, Clenet F, Shaldubina A, Belmaker RH, Bourin M. The antidepressant activity of inositol in the forced swim test involves 5- $\mathrm{HT}_{2}$ receptors. Behav Brain Res. 2001;118:77-83.

55 Redrobe JP, Bourin M. Partial role of 5- $\mathrm{HT}_{2}$ and $5-\mathrm{HT}_{3}$ receptors in the activity of antidepressants in the mouse forced swimming test. Eur J Pharmacol. 1997;325:129-135. 